\title{
A contribution to the human capital investment debate vis-à-vis economic growth: the case for Nigeria
}

\section{Lasbrey ANOCHIWA}

Department of Economics and Development Studies, Alex Ekwueme Federal University Ndufu, Nigeria

lasbrey.anochiwa@funai.edu.ngmail

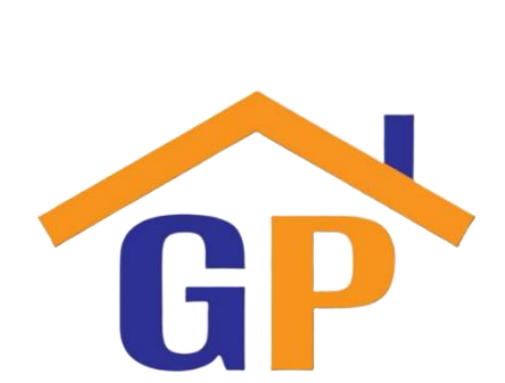

Article History

Received on 18 December 2020

$1^{\text {st }}$ Revision on 20 December 2020

$2^{\text {nd }}$ Revision on 3 January 2021

Accepted on 11 January 2021

\begin{abstract}
Purpose: Human capital development is essentially vital in enhancing economic growth and Nigeria needs to grow. This study investigates the contribution of human capital to growth in Nigeria.
\end{abstract}

Research methodology: We have disaggregated the article's variables into different models, for a better result. We employed the Autoregressive Distribution Lag (ARDL) framework to examine the relationship between the variables. E-views software was used as applied in Akbari, Chude and Chude (2013).

Result: The result shows that there exists a long-run relationship between the human capital indices, education and health in Nigeria and economic growth. Though the coefficient is positive but has a statistically insignificant relationship with human capital development and economic growth.

Limitation: The study was hindered by the availability of data.

Contribution: It is satisfactory to know from the study that human capital is still relevant in explaining growth in Nigeria.

Keywords: Human capital, Economic growth, Development

How to cite: ANOCHIWA, L. (2021). A contribution to the human capital investment debate vis-à-vis economic growth: the case for Nigeria. Annals of Human Resource Management Research, 1(1), 15-28.

\section{Introduction}

Human capital development has come to stay as pivotal in the economic growth of any country today. For some apparent reason, knowledge capital has led many countries out of the shackles of underdevelopment. The pace at which any country could 'leap frog' or catch up to growth depends mostly on how that economy invests its resources in developing human potentials. The world has been thrown into confusion by COVID-19 to realize it has not gotten enough reliable trained medical personnel to manage the pandemic. The development of human capital has posed great challenges to most developing countries not because it does not have the capacity to develop its own Research and Development (R\&D) but it has chosen to be spoon-fed by advanced economies at the peril of its development (Anochiwa lasbrey et al., (2018). Regrettably, the little manpower grown in such economies like Nigeria are also lost to "Brain Drain". It is worthwhile that human capital is harnessed and mobilized to fully participate in the development process. It stands to be corrected that human capital is the most valued asset today as against physical capital. This is for the purpose of providing the economy with healthy and trained human resource required for economic growth and development. According to (Collier et al 1999, 2005; OECD, 2001; Romer 1989) creation of human capital is about people hiring, promoting and investing by way of recruitment, training, coaching and mentoring, corporate development and handling human resources. Human capital resources is an investment because it does not just exist anywhere without training (Schultz, T. W. 1961a; Bils, M., \& Klenow, P. J. 2000), it is a vital input in an organization framework (Anochiwa and Maduka 2014). 
The progress made in understanding the contribution of human capital to growth is derived from the works of Mankiw, Romer and Weil (1992) and others. Other pioneering works related to human capital at the early stage include (Schultz, 1961a and Becker, 1964). Development is said to take when it affects people's ability to organize themselves objectively and harness their resources with little interference from outside. Though development is a multifaceted phenomenon, nevertheless, improvement in human capital still remains one of the determinants of growth. This is perhaps why most countries that have entered as emerging economies invest massively on it as well as infrastructure.

To further set a standard to monitor and evaluate each country's level of human development, the United Nations Educational Scientific and Cultural Organization (UNESCO) set a bench mark for each country to follow. That minimum standard stipulates that each country should aim to allocate at least 26 per cent of its annual budget to education; but it is sad to know from statistics that Nigeria have not gotten close that minimum standard since decades. For example, between the periods 1980 to 2018 allocation of budget to education and health has been fluctuating around 10 percent. For example, in 2012 it was (8.20 percent), 2013(8.55 percent), and 2014 (9.94 percent), until 2015 when a significant drop in allocation to education was recorded (7.74 percent). In 2016, education sector had its second worst budgetary allocation in 10 years (CBN, 2016; 2017).

The health sector has also undergone high rate of underfunding over the years, in 2000 the health sector was allocated about $1.89 \%$ of the total budget, in 2001, it stood at $2.23 \%$, in 2002, it reduced to $1.81 \%$, in 2003, the sector was allocated $3.14 \%$ of total budget, in 2004, it was 2.91, in 2005, it stood at 2.91, in 2006, the allocation was 2.45, and in 2007, it was 3.00, In 2008, it reduced to 2.53, and then stood at 2.91 in 2009, In 2010, the budget was at 3.2\%, and in 2011 it stood at 5.7, it reduced further in 2012 to $5.8 \%$, and then rose to $5.5 \%$ in 2013, in 2014, it stood at $4.4 \%$, In 2015, the federal budgetary allocation to the education sector stood at 5.5\% of the national budget, In 2016, about $4.23 \%$ was allocated to the sector, In 2017 , the budgetary allocation to the health sector further fell to $4.16 \%$ (WHO, 2019). This mode of allocation to health sector and education is discouraging. This level of under-funding may certainly affect the growth of human development. This is why an examination of human capital to economic growth is relevant at this point in time. In particular, we are writing at a time when the two critical factors that are driving growth and sustainability of human life are education and health. At this time of COVID-19, these principal sectors must be given consideration above other sectors. Therefore, this study's main objective is to investigate the relationship between human capital development and economic growth in Nigeria.

\section{Literature review}

It is good brain that can effortlessly contribute to development in the $21^{\text {st }}$ century. It is the trained mind that can be able to influence their environment and also help others gain relevance in the society. The learning so acquired helps the individual to maximize his potentials in life. For reasons associated with lack of technical know-how and scarcity of capital, and abundance of labour supply, developing countries prefer economic activities that favour labour- techniques. Nevertheless, every country needs to possess a minimum threshold of human capital to appropriate foreign capital gains. In fact, possession of a minimum benchmark of human capital is one of the determinants of foreign direct investment (FDI). Nations must invest in Research and development to improve their technological capacity. Note also that technological capacity or what is often referred to as capacity building is gotten through technological education. It is the enabler to adapt or adopt imported technology (Hayashi, 2002). In other words, Author Lewis postulation of 'unlimited labour' models of growth may clearly be irrelevant today.

In this $21^{\text {st }}$ century, employment of Labour must be considered in terms of efficiency and the marginal product of labour. That means what labour generates in a business or company's operation determines its worth and value and not the number of people involved or employed. It is the healthy body and mind that could meaningfully contribute to sustainable growth. When society improves its budgetary allocation to health and education, she will improve productivity (World Bank. 2017; Collier P and Gunning, J 1999). Many third world countries are underdeveloped due to neglect in investing human 
capacity building. Again, deficiencies in investing in infrastructure, especially in the rural sector, reinforce such a country's backwardness. The differences in human capital and infrastructure may account for the wide gap between African and Asian countries.

Many Scholars have given vent to emphasis on human capital as growth variables, for example (Romer 1989; Barro, 1991; Becker 1964 and Lucas 1988; 1990). Earlier economist has given more attention to physical capital as an engine of growth. There is a paradigm shift on the focus of what propels growth; in the past significant determinants of growth was considered in terms of physical capital, but as the world moves towards digital era it becomes increasingly difficult to rely on it for growth. Development economist has drawn global attention towards more knowledge-based sectors. The outcome of the paradigm shift is increased demand by institutions and policy makers to invest in education that will train critical skills for development (Bils, M., \& Klenow, P. J. 2000; Ojokuku, R. M. \& Sajuyigbe, A. S. (2015).

There is empirical evidence both at the third world level or developed economies of significant relationship between human capital and economic growth. Literature bound that higher education closes technological gap faster than possession of physical capital (Ben Habib and Spiegel 1994; Barro \& Sala-Martin (1995), steady state growth depends on human capital development (Aghion and Howitt 1992), rate of human capital depends on education and training (Lucas 1988; 1990), double research and Development and see the doubling of output growth (Aghion and Howitt 1992), the Asian tiger miracle was as a result of investment in education (Coe, D.T. and E. Helpman 1995) . As earlier stated, studies have shown both locally and internationally the relevance of increase in development of human capital, therefore the need for this study. What appears to be a general outlook is that human capital enhances growth. We shall look at some of the empirical works in the literature below.

Simoes (2006) examined the relationship between expenditure on education and economic growth, laying special emphasis on other variables that determine technological change. This study was based on apnal data frame work. The study drew sample from 23 OECD countries between 1960 to 2000 using Benhabib focused on a sample of 23 OECD countries from 1960- 2000 and used an extended and augmented and Spiegel (1994) growth specification. It also applied the Employing GMM estimator for robustness. The results of findings show that there is a positive significant relationship between education and economic growth especially in tertiary schooling through technology diffusion and domestic innovation activities.

Earlier Saad and Kalakeeh (2009) examined the relationship between government expenditure and education, health, agriculture, and defense on Lebanon's economic growth for the period 1962-2007. In their methodology they applied OLS and co-integration. Their findings show that education expenditure has a positive and significant effect on economic growth in the long run and negative effect in the short run. Again, other variables like health expenditure were found to positively correlate with human capital growth and significantly related to economic growth in the short run. In their recommendation, they advocated for government to increase interest in the education sector by increasing budgetary allocation to the education sector. It is believed that all things being equal, the more we increase education funding the more we enhance skills that will be released to enhance growth of the economy. This result is found to be robust and consistent across all methods in the literature.

Sankay, Ismail and Shaari (2010) examined the relationship between human capital development and Nigeria's economic growth. The time series data obtained is between the periods 1970 to 2008 . They employed as a technique Johansen co-integration and vector error correction analysis to determine this relationship. In carrying out the research, they applied some of the following macroeconomic variables: real recurrent expenditure on education, real capital stock, real capital expenditure on education, real gross domestic product, total school enrolments and labor force are used to proxy human capital development. The result of their findings shows that human capital development has a statistical significant relationship with economic growth. 
Akbari et al. (2012) examined the relationship between human capital development and economic growth in Iran between 1970 and 2010. They considered both the long run and the short run effects. The article employed auto-regressive distribution lag model for its analysis. Foreign direct investment (FDI), government expenditure on education and labour force are the variables used for the study. The results of findings show significant positive relationship between human capital and economic growth in Iran. The researchers were hopeful that their findings will attract the attention of government towards improvement of human capital development.

Following after Akbari, Chude and chude (2013) also examined the relationship between public expenditure in education and Nigeria's economic growth. They paper made use of Error Correction Model (ECM) in their analysis. Their findings show that Total Expenditure on Education is highly and statistically significant, and it also has a positive relationship on economic growth in Nigeria in the long run. In another study carried out by Adegoke, et al (2012) still on the relationship between human capital development and economic growth in Nigeria using correlation; it found that investment in education and health has positive correction with economic growth and development. This finding goes to show the impact of education which stands as proxy for human capital is very relevant to growth. Conclusively, the study recommends that priority should be accorded to human development through improvement in education.

Anochiwa and Maduka (2014) examined the relationship between human capital, infrastructure and economic growth in Nigeria from 1970-2010 through methodological use of Unit root tests, cointegration tests, and Error correction model. On the choice of variables, the researchers made use of variables such as real gross domestic product which is used as a proxy for economic growth, and other variables such as foreign direct investment, stock of human capital, inflation rate, infrastructure development, and domestic capital formation. The findings show a positive relationship between human capital and economic growth in Nigeria. Other findings show that infrastructural expenditure is positively related with economic growth.

Miyanda Hakooma and Venkatesh Seshamani (2017) investigated the relationship between human capital development's impacts on economic growth in Zambia from 1970 to 2013. Johansen cointegration and error correction models (ECM) was employed to test the relationship with variables used to measure government expenditure on health and secondary school enrollment. The projected longer-term models show that the major contributor to the actual GDP growth per person led by educational, human resources and secondary-school enrolment is health in the form of healthcare funded by public health spending. Olusogo Olamide Ogunleye (2017) conducted a research study on the relationship between human capital development and economic growth in Nigeria from 1981 to 2015, employing the ordinary least squares regression analysis. The study made use of variables such as primary, secondary and tertiary school enrollments, and government expenditure on health. The findings show that there is a positive relationship between human capital development and economic growth in Nigeria.

In conclusion, it will be recalled that in the follow up to the literature review, we have postulated based on observations that human capital development enhances growth, but having gone through few of the literature we can also attest to this based on the various findings that human capital enhances growth; we have equally established that growth in education expenditure accelerates growth, why it has become a debate is the luster attitude of government in increasing budget to education sector over the years and the non-existence R\&D in virtually all sectors of the economy. Does it mean lack of knowledge (ie ignorance) or deliberate attempt to stifle growth or both? This is why we want to take a second look on these variables that ginger growth and see whether it is still consistent, to add to the literature debate on the issue.

\section{Research methodology}

The ex-post facto research design was used in this report. Ex-post-facto design is a systemic, observational study in which the researcher can not explicitly influence independent variables, whether they have manifested themselves or are not inherently manipulated. (Akuezuilo, 1990). This 
research favors the ex-post facto design because it involves events that have already taken place. The reason why this design is being used is because availability of data, that is, secondary data which will be gotten from Central Bank of Nigeria statistical bulletin and economic review of various years. Gross domestic product (GDP) is the dependent variable, specified to depend on human capital development indices (Government expenditures on education and health and human capital as an aggregate).

\section{Estimation Technique}

This research work is based on Auto Regressive Distributed Lag (ADRL) model, and it is used to establish the relationship between human capital development and economic growth in Nigeria. The ARDL multiple regression analysis aims to determine the effect of the independent variables on the dependent variable. To improve on the linearity of the model, log is introduced in the model. In this study Augmented Dickey Fuller (ADF) test statistic is employed to identify the order of integration. The Bound test otherwise referred to Autoregressive Distributed Lag is used to examine if the variables are co-integrated; to estimate the ARDL Error Correction Model (ECM) comes after cointegration has been confirmed. The evaluation of results will be based on three criteria's; Economic criteria, statistical criteria and econometrics criteria.

\section{Model Specification}

The importance of economic modeling is to represent the argument under investigation in a manner that the researcher will be able to assign numerical values to the concept used. It is important to note that this research work will focus on the Endogenous growth theory also known as the new growth theory.

Borrowing from the Cobb Douglas production function; $\mathrm{Y}=\mathrm{Z}^{\beta} \mathrm{ER}(\mathrm{AL})^{1-\beta-\mathrm{Z}}$

Where Z, E, \& R are respectively total stock of physical \& human capital and technical capital, L, A measures the size of the labor force and productivity.

This model can take the form of

$\mathrm{Y}=\mathrm{zd}^{\beta 1} \mathrm{zf}^{\mathrm{b} 2} \mathrm{E}^{\mathrm{b} 3} \mathrm{R}^{\mathrm{b} 4}(\mathrm{AL})^{\mathrm{b} 5}$

Where $\mathrm{Y}=$ National output

$\mathrm{Zd}=$ Stock of domestic capital

$\mathrm{Zf}=$ Stock of human capital

$\mathrm{B} 1, \mathrm{~b} 2, \mathrm{~b} 3$, b4 and b5 are coefficients

This model can be modified following the Grossman-Helpman (1991) model on human capital and economic growth and be stated as follows;

$\mathrm{GDP}=\mathrm{f}(\mathrm{HDI}, \mathrm{TRD}, \mathrm{GFCF}, \mathrm{EXCR}, \mathrm{CPI})$

Where GDP is the dependent variable and a proxy for Economic growth, and the independent variables are given as HDI representing human development indices, the human development indices comprises of EDU which is the expenditure government made on education, HLTH which represents expenditure government made on health and HCAP which captures human capital as an aggregate, TRD represents trade openness, GFCF represents gross fixed capital formation, EXCR represents exchange rate and CPI represents consumer price index. This can be expressed in a more explicit functional relationship in the following equation;

$\mathrm{GDP}_{\mathrm{t}}=\alpha_{0}+\alpha_{1} \mathrm{HDI}+\alpha_{2} \mathrm{TRD}+\alpha_{3} \mathrm{GFCF}+\alpha_{4} \mathrm{EXCR}+\alpha_{5} \mathrm{CPI} \mu_{\mathrm{t}}$

Note that TRD, GFCF, EXCR, and CPI are other control variables determining economic growth.

$\mu$ represents the error term

The logarithm transformation for equation 4 then becomes;

$\ln \mathrm{GDP}=\alpha_{0}+\alpha_{1} \ln (\mathrm{HDI})+\alpha_{2} \ln (\mathrm{TRD})+\alpha_{3} \ln (\mathrm{GFCF})+\alpha_{4} \ln (\mathrm{EXCR})+\alpha_{5} \ln (\mathrm{CPI})$

\section{Augmented Dickey Fuller Unit Root Test}

A unit root test is conducted to examine if macroeconomic variables are stationary. 
Table 1 ADF Unit Root Test

\begin{tabular}{|c|c|c|c|}
\hline Variables & Level I(0) & First Difference & $\mathbf{I}(\mathbf{1})$ \\
\hline LNGDP & $0.032145,\{-2.94840\}$ & -3.339751 & $\{-2.9484\} *$ \\
\hline LNEDU & $-1.991344,\{-2.95711\}$ & -5.058414 & $\{-2.9571\} *$ \\
\hline LNHLTH & $-1.377690,\{-2.95711\}$ & -4.931166 & $\{-2.9571\}^{*}$ \\
\hline LNHCAP & $-1.880487,\{-2.95711\}$ & -5.160067 & $\{-2.9571\}^{*}$ \\
\hline LNTRD & $-0.737558,\{-2.94840\}$ & -4.768862 & $\{-2.9810\}^{*}$ \\
\hline LNGFCF & $1.564798,\{-2.95112\}$ & -6.760783 & $\{-2.9484\}^{*}$ \\
\hline LNEXCR & $-1.908908,\{-2.94584\}$ & -5.108290 & $\{-2.9484\}^{*}$ \\
\hline LNCPI & $-1.415341,\{-2.96776\}$ & -3.474342 & $\{-2.9511\}^{*}$ \\
\hline
\end{tabular}

NOTE: T-statistics is in parenthesis \{\} , while * shows that it is significant at $5 \%$

From the table 1 above, it is observed that all the variables were not stationary at levels but they became stationary after the first difference. This qualifies us to apply ARDL Bound test. The Bounds test says that hypothesis should be rejected if the value of computed F-statistics is greater than the upper bounds. Again, the value of the upper bound is accepted if the F-statistic is less than the lower bounds value. Nevertheless, when there is a tie, that is, if the computed F-statistic fall within the lower and upper bound, the ARDL co-integration test will be said to be inconclusive. The ARDL bounds test for the three specifications is conducted independently as below.

Table 2: ARDL Bounds Test Result

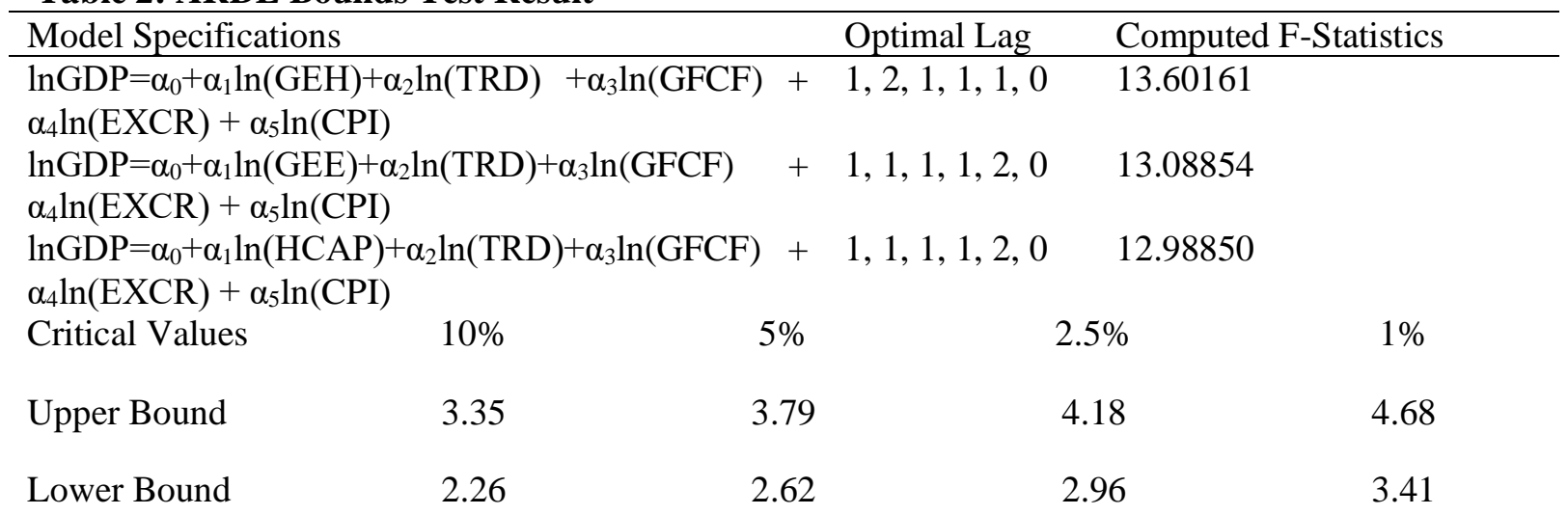

The results for the bounds test for the three models specified above are presented in table 2 above. The computed F-statistic for each of the tests (13.60161) (13.08854) (12.98850) are greater than all the upper bound critical value at $1 \%$ level of significance, the null hypothesis of no co-integration among the variables should be rejected. The implication of the figures above confirms existence of a long-run relationship among the dependent (LGDP) and the explanatory variables in each of the models. This result of co-integration, empowers the researcher to proceed to estimate the ARDL long run and Error Correction Model.

\section{Autoregressive Distributed Lag (ARDL)}

What we can deduce from the results is that a long run relationship exists among the variables. The results of the estimations are presented in tables below:

Specification 1

$\mathrm{LnGDP}=\alpha_{0}+\alpha_{1} \ln (\mathrm{HLTH})+\alpha_{2} \ln (\mathrm{TRD})+\alpha_{3} \ln (\mathrm{GFCF})+\alpha_{4} \ln (\mathrm{EXCR})+\alpha_{5} \ln (\mathrm{CPI})$

Table 3: Results

Long Run Coefficients

\begin{tabular}{|c|c|c|c|c|}
\hline Variable & Coefficient & Std. Error & $\mathrm{t}$-Statistic & Prob. \\
\hline LNHLTH & 0.097540 & 0.037163 & 2.624657 & 0.0151 \\
\hline
\end{tabular}




\begin{tabular}{lllll} 
LNTRD & 3.593810 & 0.307452 & 11.689012 & 0.0000 \\
LNGFCF & -0.298160 & 0.128698 & -2.316746 & 0.0298 \\
LNEXCR & -0.066233 & 0.029708 & -2.229429 & 0.0358 \\
LNCPI & -0.154813 & 0.053870 & -2.873817 & 0.0086 \\
C & 0.588623 & 1.148864 & 0.512352 & 0.6133 \\
\hline \hline
\end{tabular}

In the long run, health expenditure and trade openness variables show that the existence of a positive relationship between these variables and economic growth in Nigeria to the extent that a relative increase in health expenditure and trade openness increases GDP of the economy by 0.097540 , and 3.593810 respectively. The findings also show that, a relative increase in gross fixed capital formation, exchange rate and consumers price index, will decrease GDP in the economy by 0.298160 , 0.066233 and 0.154813. All the independent variables are significant in the long run at 5\% significance level.

\section{Specification 2}

$\operatorname{lnGDP}=\alpha_{0}+\alpha_{1} \ln (\mathrm{EDU})+\alpha_{2} \ln (\mathrm{TRD})+\alpha_{3} \ln (\mathrm{GFCF})+\alpha_{4} \ln (\mathrm{EXCR})+\alpha_{5} \ln (\mathrm{CPI})$

\section{Table 4 Result}

Long Run Coefficients

\begin{tabular}{lllll}
\hline \hline Variable & Coeff. & Std. Error & t-Statistic & Prob. \\
\hline \hline LNTRD & 4.141257 & 0.490457 & 8.443663 & 0.0000 \\
LNGFCF & -0.462650 & 0.244073 & -1.895539 & 0.0707 \\
LNEXCR & -0.002561 & 0.058553 & -0.043735 & 0.9655 \\
LNCPI & -0.093717 & 0.073111 & -1.281842 & 0.2127 \\
LNEDU & 0.002984 & 0.035189 & 0.084794 & 0.9332 \\
C & -0.231184 & 1.606015 & -0.143949 & 0.8868 \\
\hline \hline
\end{tabular}

In the result above, the long run coefficients of the equation shows that education expenditure and trade openness has positive relationship with Nigeria's economic growth, in the sense that a relative increase in education expenditure and trade openness will relatively increase GDP by 0.002984 and 4.141257 respectively. The other control variables were not significant.

\section{Specification 3}

$\mathrm{LnGDP}=\alpha_{0}+\alpha_{1} \ln (\mathrm{HCAP})+\alpha_{2} \ln (\mathrm{TRD})+\alpha_{3} \ln (\mathrm{GFCF})+\alpha_{4} \ln (\mathrm{EXCR})+\alpha_{5} \ln (\mathrm{CPI})$

Table 5: Results

Long Run Coefficients

\begin{tabular}{|c|c|c|c|c|}
\hline Variable & Coefficient & Std. Error & t-Statistic & Prob. \\
\hline LNTRD & 4.130461 & 0.486599 & 8.488423 & 0.0000 \\
\hline LNGFCF & -0.461677 & 0.241771 & -1.909565 & 0.0687 \\
\hline LNEXCR & -0.006162 & 0.057726 & -0.106751 & 0.9159 \\
\hline LNCPI & -0.103085 & 0.073656 & -1.399561 & 0.1750 \\
\hline LNHCAP & 0.011840 & 0.035671 & 0.331916 & 0.7430 \\
\hline $\mathrm{C}$ & -0.177283 & 1.601825 & -0.110675 & 0.9128 \\
\hline
\end{tabular}

Here, the long run coefficients show that human capital is positive but not significant while trade openness is both positive and significant relationship with economic growth. The other control variables are positive but not significant. 


\section{Estimated Short-Run Coefficients and ECM of the ARDL Model}

Below are results from the ARDL model for each of the specifications in the estimated short run coefficient.

\section{Specification}

$\mathrm{LnGDP}=\alpha_{0}+\alpha_{1} \ln (\mathrm{HLTH})+\alpha_{2} \ln (\mathrm{TRD})+\alpha_{3} \ln (\mathrm{GFCF})+\alpha_{4} \ln (\mathrm{EXCR})+\alpha_{5} \ln (\mathrm{CPI})$

Table 6 Results (test for ECM)

\begin{tabular}{|c|c|c|c|c|}
\hline Variable & Coefficient & Std. Error & t-Statistic & Prob. \\
\hline D(LNHLTH) & 0.013714 & 0.008251 & 1.662140 & 0.1101 \\
\hline D(LNTRD) & 4.041498 & 1.469044 & 2.751107 & 0.0114 \\
\hline $\mathrm{D}(\mathrm{LNGFCF})$ & -0.026892 & 0.037944 & -0.708724 & 0.4856 \\
\hline D(LNEXCR) & -0.046815 & 0.015582 & -3.004435 & 0.0063 \\
\hline D(LNCPI) & -0.057045 & 0.023370 & -2.440936 & 0.0228 \\
\hline ECM(-1) & -0.368473 & 0.080015 & -4.605059 & 0.0001 \\
\hline
\end{tabular}

\begin{tabular}{lllll}
\hline \hline R-squared & 0.999958 & & Mean dependent var & 10.32580 \\
Adjusted R-squared & 0.999664 & S.D. dependent var & 0.525868 \\
S.E. of regression & 0.009640 & Akaike info criterion & -6.798403 \\
Sum squared resid & 0.000372 & Schwarz criterion & -5.483290 \\
Log likelihood & 141.1736 & Hannan-Quinn criter. & -6.355908 \\
F-statistic & 3400.655 & Durbin-Watson stat & 2.503962 \\
Prob(F-statistic) & 0.000000 & & \\
\hline \hline
\end{tabular}

Short-Run Diagnostic Tests

Serial Correlation LM Test $=3.134170(0.0644)$

Normality Test $=1.154850(0.561342)$

Heterosckedasticity $=0.533066(0.4706)$

The results of findings show that the ECM is rightly signed and negative. It is significant at 5\%, which shows a long-term relationship among the model variables. The coefficient of -0.368473 defines the speed of adjustment, which is approximately $36.8 \%$. This is the speed any disequilibrium in GDP per capita in the previous period could be adjusted.

Again, the estimated coefficients of trade openness and health expenditure with the GDP is statistically not significant though positive. When there are small increase in the two variables in the short run, it leads to a relative increases in GDP per capita income by 0.013714 and 4.041498 respectively. The Durbin-Watson Statistic is within the acceptable region so is the R-square.

The regression is typically distributed and there exists no heteroskcedasticity.

Lastly, Cumulative Sum (CUSUM) and Cumulative Sum Squares (CUSUMSQ) is applied to determine the stability of the long-run and the short-run coefficient of movements for the ARDL Error Correction Model. If the CUSUM and CUSUMSQ statistics' plots stay within the critical bounds of 5 percent significance level on the graph, the model is said to be stable. Figure 1 and 2 below shows that the ARDL Error Correction model is stable because the CUSUM and CUSUMSQ statistics fall within the $5 \%$ critical bounds. 
Fig 1: Cumulative sum (CUSUM) 1

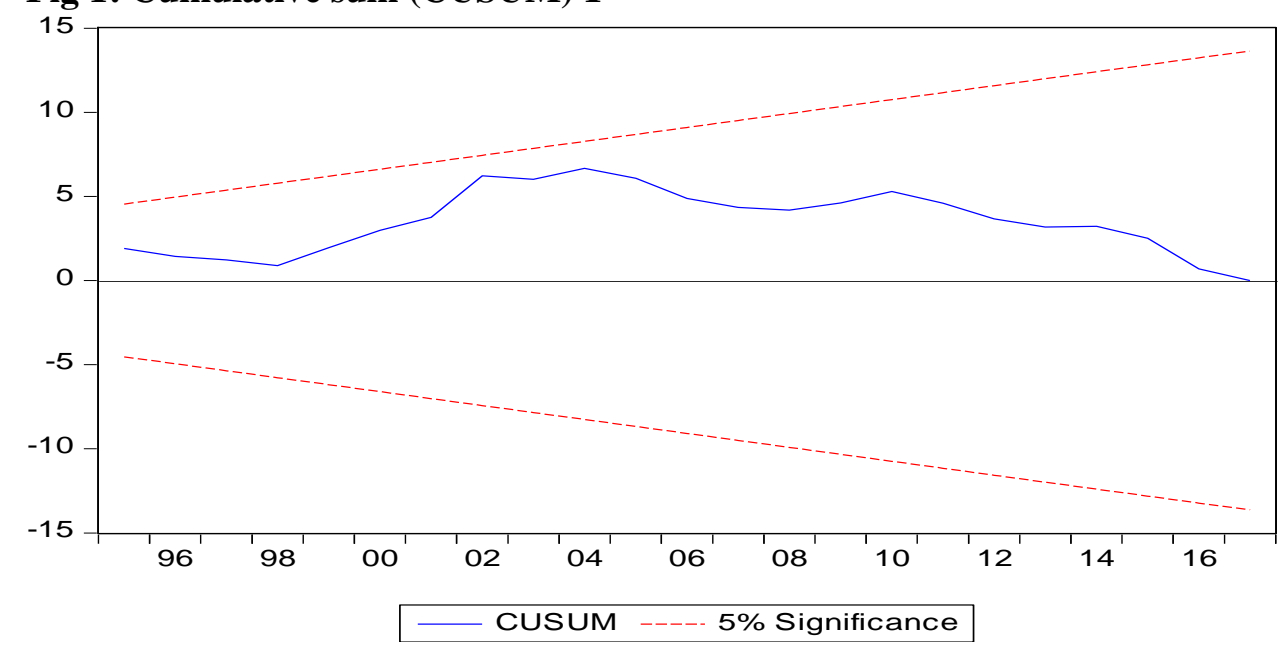

Fig 2: Cumulative sum (CUSUM) 2

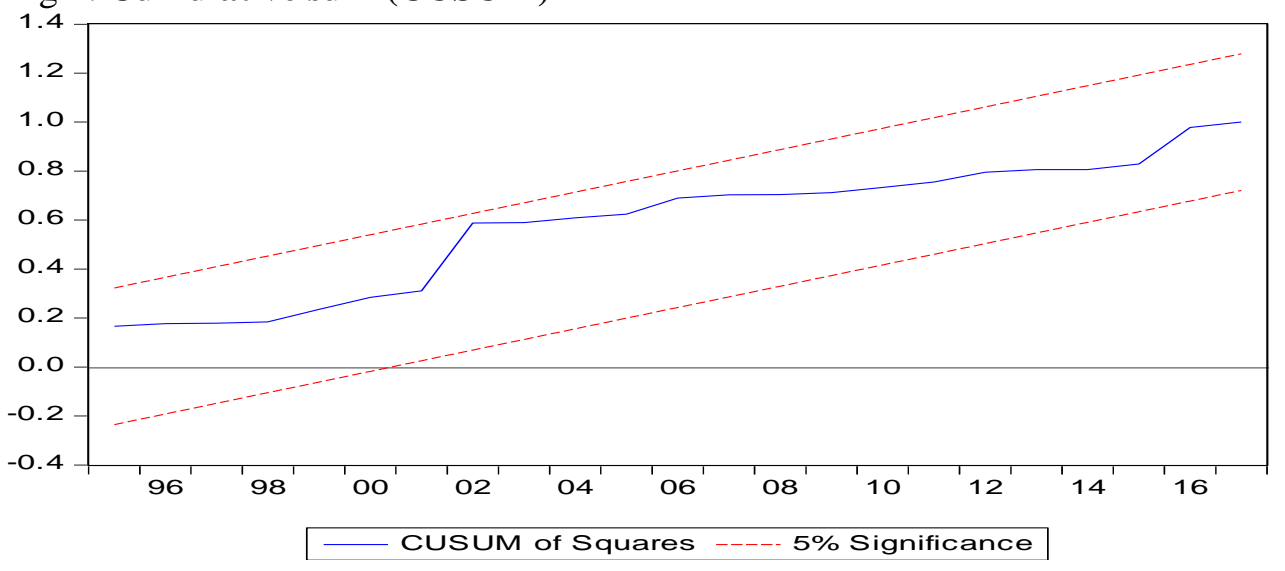

Specification

$\ln \mathrm{GDP}=\alpha_{0}+\alpha_{1} \ln (\mathrm{EDU})+\alpha_{2} \ln (\mathrm{TRD})+\alpha_{3} \ln (\mathrm{GFCF})+\alpha_{4} \ln (\mathrm{EXCR})+\alpha_{5} \ln (\mathrm{CPI})$

Table 7: Results (test for ECM)

\begin{tabular}{lllll}
\hline \hline Variable & Coefficient & Std. Error & t-Statistic & Prob. \\
\hline \hline D(LNTRD) & 5.174404 & 1.413118 & 3.661694 & 0.0013 \\
D(LNGFCF) & -0.051873 & 0.040049 & -1.295239 & 0.2081 \\
D(LNEXCR) & -0.034690 & 0.016970 & -2.044164 & 0.0526 \\
D(LNCPI) & -0.101370 & 0.048078 & -2.108435 & 0.0461 \\
D(LNCPI(-1)) & 0.057222 & 0.043711 & 1.309106 & 0.2034 \\
D(LNEDU) & 0.000707 & 0.008326 & 0.084877 & 0.9331 \\
ECM(-1) & -0.236837 & 0.075844 & -3.122686 & 0.0048 \\
\hline \hline
\end{tabular}

$\begin{array}{llll}\text { R-squared } & 0.998883 & \text { Mean dependent var } & 10.28053 \\ \text { Adjusted R-squared } & 0.998348 & \text { S.D. dependent var } & 0.543222 \\ \text { S.E. of regression } & 0.022078 & \text { Akaike info criterion } & -4.522633 \\ \text { Sum squared resid } & 0.011211 & \text { Schwarz criterion } & -3.989371 \\ \text { Log likelihood } & 91.14608 & \text { Hannan-Quinn criter. } & -4.338551 \\ \text { F-statistic } & 1869.156 & \text { Durbin-Watson stat } & 1.958155 \\ \text { Prob(F-statistic) } & 0.000000 & & \end{array}$




\section{Short-Run Diagnostic Tests}

Serial Correlation LM Test $=2.853252(0.0801)$

Normality Test $=0.954360(0.620531)$

Heterosckedasticity $=1.659043(0.2070)$

What can be deduced from the result is that the error term is negative and significant at 5\% significance level. This result justifies the confirmation of the existence of a long-term relationship among the variables. With -0.236837 coefficients, the model approximates the speed of adjustment to 23.6\%. This result signifies and suggests that any disequilibrium in GDP per capita resulting from the shock in the previous period will be corrected at the rate of $23.6 \%$. When this happens, the disequilibrium will converge to the long-run equilibrium in the current period.

The Durbin-Watson Statistic shows the absence of autocorrelation and the R-square is significant. From the result we observe absence of auto-correlation and heterosckedasticity.

Lastly, the Cumulative Sum (CUSUM) and Cumulative Sum Squares (CUSUMSQ) graph is applied to establish the stability of the long-run coefficient and the short-run movements for the ARDL Error Correction Model. Figure 3 and 4 show that ARDL Error Correction model is stable because the CUSUM and CUSUMSQ statistics fall within the $5 \%$ critical bounds.

Fig 3

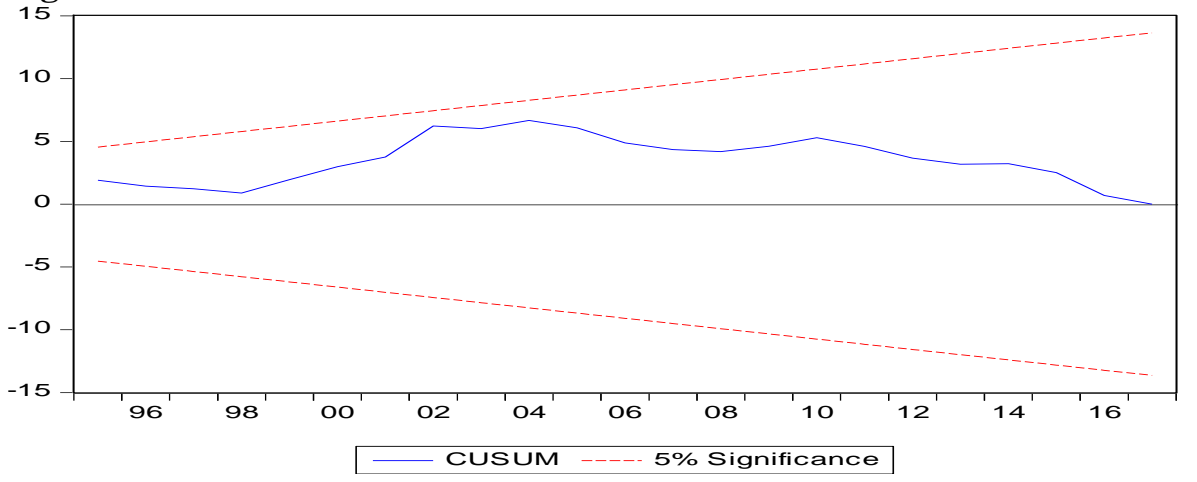

Fig 4

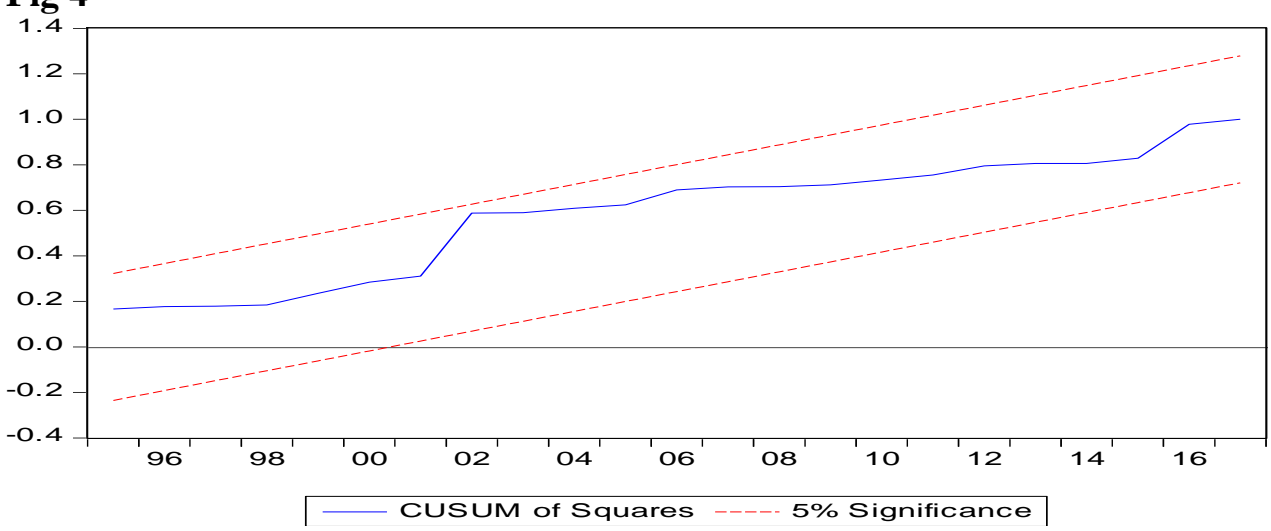

Specification

$\ln \mathrm{GDP}=\alpha_{0}+\alpha_{1} \ln (\mathrm{HCAP})+\alpha_{2} \ln (\mathrm{TRD})+\alpha_{3} \ln (\mathrm{GFCF})+\alpha_{4} \ln (\mathrm{EXCR})+\alpha_{5} \ln (\mathrm{CPI})$

Table 8 Results (test for ECM)

Cointegrating Form

\begin{tabular}{lllll}
\hline \hline Variable & Coefficient & Std. Error & t-Statistic & Prob. \\
\hline \hline D(LNTRD) & 5.035790 & 1.411452 & 3.567807 & 0.0016 \\
D(LNGFCF) & -0.052922 & 0.039838 & -1.328411 & 0.1971
\end{tabular}




\begin{tabular}{|c|c|c|c|c|}
\hline D(LNEXCR) & -0.035251 & 0.016959 & -2.078584 & 0.0490 \\
\hline D(LNCPI) & -0.103181 & 0.048119 & -2.144274 & 0.0428 \\
\hline D(LNCPI(-1)) & 0.055420 & 0.043230 & 1.281975 & 0.2126 \\
\hline D(LNHCAP) & 0.002819 & 0.008486 & 0.332210 & 0.7427 \\
\hline ECM(-1) & -0.238100 & 0.075730 & -3.144072 & 0.0045 \\
\hline R-squared & 0.998888 & \multirow{7}{*}{\multicolumn{2}{|c|}{$\begin{array}{l}\text { Mean dependent var } \\
\text { S.D. dependent var } \\
\text { Akaike info criterion } \\
\text { Schwarz criterion } \\
\text { Hannan-Quinn criter. } \\
\text { Durbin-Watson stat }\end{array}$}} & 10.28053 \\
\hline Adjusted R-squared & 0.998356 & & & 0.543222 \\
\hline S.E. of regression & 0.022028 & & & -4.527107 \\
\hline Sum squared resid & 0.011161 & & & -3.993845 \\
\hline Log likelihood & 91.22437 & & & -4.343025 \\
\hline F-statistic & 1877.546 & & & 1.967566 \\
\hline Prob(F-statistic) & 0.000000 & & & \\
\hline
\end{tabular}

\section{Short-Run Diagnostic Tests}

Serial Correlation LM Test $=2.736664(0.0879)$

Normality Test $=1.245705(0.536412)$

Heteroskedasticity Test $=1.674923(0.2049)$

The result for the specification shows that the ECM is negative and significant at a 5\% significance level, thus validating the existence of a long-term relationship among the model variables. The short run relationship is such that a relative increase in the variables relatively increases GDP per capita income by $5.035790,0.055420$ and 0.002819 respectively.

The Durbin-Watson Statistic is rightly signed, autocorrelation normally distributed and no heterosckedasticity.

Lastly, the Cumulative Sum (CUSUM) and Cumulative Sum Squares (CUSUMSQ) graph is drawn to confirm stability of the long-run coefficient and the short-run movements for the ARDL Error Correction Model.

\section{Fig 5}

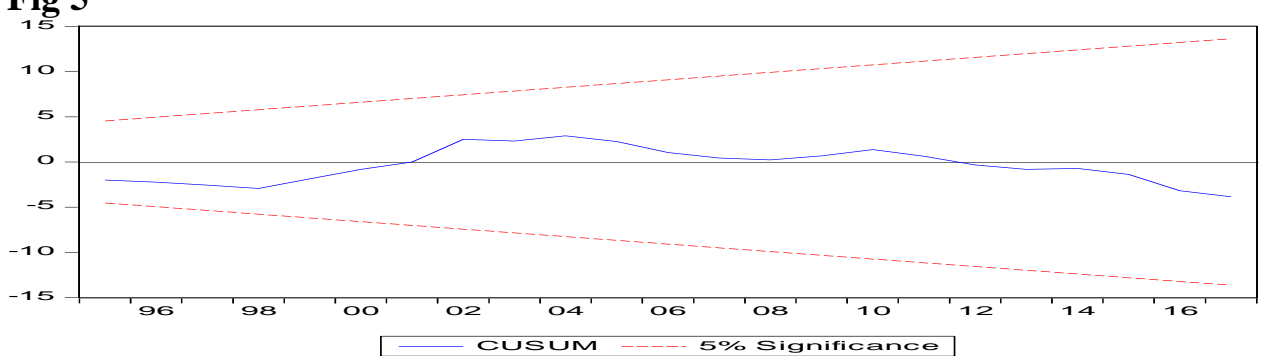

Fig 6

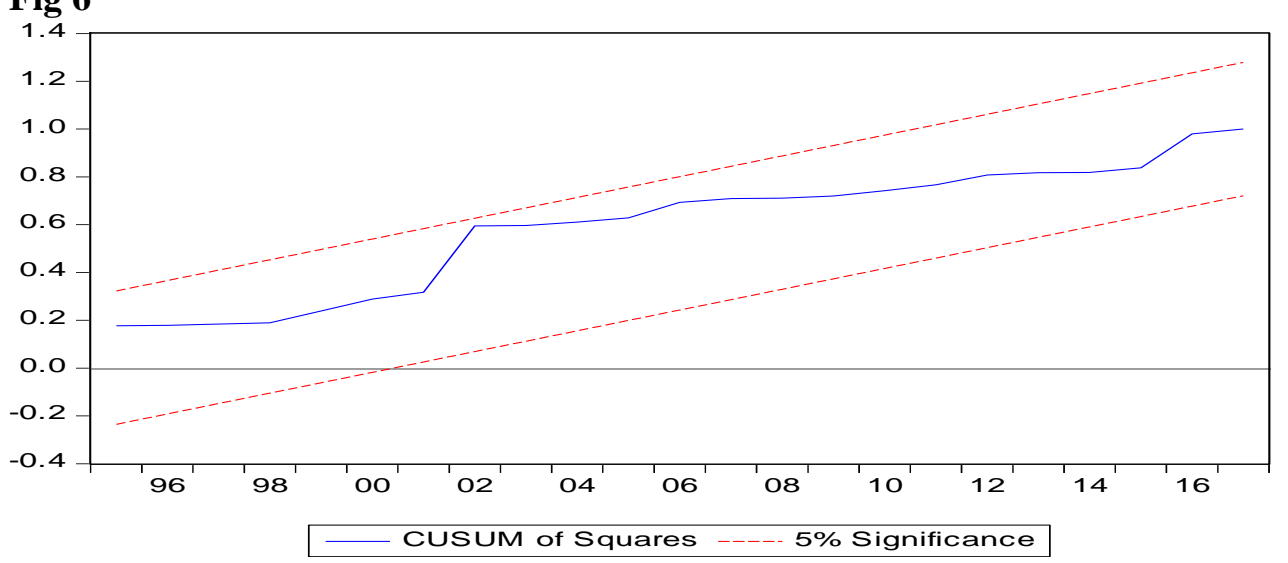

\section{Discussion/ policy implications}

Our findings suggest that expenditure on health has the potential to stimulate growth through various channels. In other words, there exists a positive relationship between expenditure on health and 
economic growth whether in the long or short run. This finding is in line with Saad and Kalakeeh (2009), Miyanda Hakooma and Venkatesh Seshamani (2017) and others that has been mentioned in the literature. Nevertheless, expenditure on health is statistically significant in the long run but not in the short run. One explanation for this is decline in the percentage of allocation to the Health sector in Nigeria's budget over the years. Another reason could be associated with the gestation period which is the number of years it takes to begin to see results. Other reasons associated with this is low quality of health facilities or services dominant in Nigeria, decaying infrastructure, medical practitioners whose moral has been weakened by unfavourable government policies. It is important to establish a public financial structure that connects particular spending and income decisions and ensures the use as straightforward as possible of the allocated fund. Whereas, attention has been on human capital development through expenditure on health and education, yet we know with diverse sicknesses ravaging the world today, every country ought to be ready for emergencies that can come like coronavirus pandemic. Health care workers should be educated and retrained to be more effective and hire more people in the health care sector to generate growth not just in the industry but in the economy as a whole.

Government Expenditure on education has a positive relationship with economic growth both in the long run and short run, and this in support of Chude and chude (2012) however, it is not significant. The reason could be associated with the salutary budget allocation to the sector. Again, Human capital is positive both in the long run and in the short run but insignificant in both periods. Expenditure on human capital development is poor and this affects growth significantly.

\section{Conclusion}

We have attempted to examine the relationship between government expenditure on education on one hand and human capital development on another vis-à-vis economic growth. Our findings show that the relations are positive on both short and long-run phenomenon, but insignificant on both periods under review. It is a debate in Nigeria due to the little attention paid to it over the years. Government unwillingness to invest in human capital development would seem to suggest that it is no longer a determinant of growth; this is why it is a debate. Our inability to draw significant result goes to demonstrate the paucity of investment in this area. This in itself justifies the importance of the two variables to growth and the government's tendency to neglect. It will continue to be a debate as long as the government of Nigeria allocates major resources to "trivial sectors" in terms of growth potentials. We therefore advocate that as a matter of urgency attention should be drawn to health and education which are critical sectors in the fight against the world current pandemic-COVID-19.

\section{Limitation and study forward}

This study is not exhaustive. Nevertheless, we suffer challenges of data and also financial constraint presently, of getting internet data for literature.

\section{Acknowledgement}

There was nonfinancial support for the study. 


\section{References}

Adegoke, Sunday and Kayode (2012). Human capital development and economic growth : a lesson from Nigeria. Journal of Economics and Sustainable Development, 3(12), 2012.

Aghion, B. and Howit T, I. O. (1992). Education expenditure and human capital development in Nigeria: Any Correlation so far. Research Paper, Ambrose Ali University, P 15-17

Akbari, M.; Moayedfar, R. \& Jouzaryan, F. (2012). Analysis of short run and long run effects of human capital on the economic growth in Iran. Economics and Finance Review, 1(11), 1-9.

Akuezuilo, B. (1990). Investments in the human capital for sustainable development in Nigeria. Journal of Economics and sustainable development. 3(2), 2012.

Anochiwa lasbrey and Ann Maduka (2014). Human capital, infrastructure and economic growth in Nigeria: an empirical evidence. IOSR Journal of Electrical and Electronics Engineering, 9(4), $1-6$.

Anochiwa lasbrey, Enyoghasim M, Agbanike T, Uwajumogu N, Basil C and Ololo K. (2018). Foreign direct investment and economic growth: literature from 1980 to 2018. International Journal of Economics and Financial Issues, 8(5), 1-10.

Barro, R. (1991). Economic growth in a cross section of countries. Quarterly Journal of Economics, 106, 407-443.

Barro, R. J.; Sala-i-Martín, X. Economic Growth (1995). New York: McGraw-Hill, 1995.

Becker, G. S (1964.). Human Capital: A Theoretical and Empirical Analysis, with Special Reference to Education. Chicago, University of Chicago Press.

Benhabib, J. and Spiegel M. 1. (1994). The role of human capital in economic development: evidence from aggregate cross-country data. Journal of Monetary Economics, 4(34), 143-173.

Bils, M., \& Klenow, P. J. (2000). Does schooling cause growth? American Economic Review, 90(December (5)), 1160-1183.

Central Bank of Nigeria. (2016). Annual statistical bulletin. Retrieved from http://www.cenbank.gov.ng

Central Bank of Nigeria. (2017). Statistical bulletin. Central bank of Nigeria, Abuja, 14(2), 155-166.

Chude Nkiru and Chude Daniel. (2013). Impact of government expenditure on economic growth in nigeria. International Journal of Business and Management Review, 1(4), 64-71.

Coe, D.T. and E. Helpman. (1995). International R-D Spillovers. European Economic Review, 39, 859-887.

Collier P and Gunning, J. (1999). Explaining African Economic performance. Journal of economic literature ECA, 1995. Human Development in Africa: 1995 Report, Economic Commission for Africa, Addis Ababa.

Grossman, G and Helpman. (1991). Innovation and Growth in the Global Economy. Cambridge, MIT Press.

Hayashi, Mitsuhiro (2002). The role of sub-contracting in SME development in Indonesia; Microlevel evidence from the metal working and machinery industry. Journal of Asian Economies $13(1), 1-26$

Lucas, R. E. (1990). Why doesn't capital flow from rich to poor countries? The American Economic Review, 92-96.

Lucas R. E. Jr. (1988). On the mechanics of economic development. Journal of Monetary Economics, 22, 3-42.

Mankiw N., Romer D., Weil D.(1992). Acontribution to the empirical of economic growth. Quarterly Journal of Economics, 107, 407-437.

Miyanda , Hakooma, \& Seshamani, Venkatesh, (2017). The impact of human capital development on economic growth in Zambia: an econometric analysis. International Journal of Economics, Commerce and Management, 5.

OECD, (2001). The well-being of nations: the role of human and social capital. Paris: OECD Publications.

Olusogo, Ogunleye, \& Owolabi, Oluwarotimi \& O. A, Sanyaolu \& O.O, Lawal. (2017). Human Capital Development And Economic Growth In Nigeria (1981 - 2015). Journal Of Business Management, 3, 17-37. 
Ojokuku, R. M. \& Sajuyigbe, A. S. (2015). Effect of human capital development on the performance of small and medium scale enterprises in Nigeria. Journal of Emerging Trends in Economics and Management Sciences (JETEMS), 6(1), 88-93.

Romer, M. P., (1989). Human capital and growth: Theory and evidence. NBER Working Paper Series, 3173

Saad, W. and Kalakech, K. (2009). The nature of government expenditure and its impact on sustainable economic growth. Middle Eastern Finance \& Economics, 38-47.

Sankay, O.J, Ismail., R. and Shaari, A. H. (2010). The Impact of human capital development on the economic growth of Nigeria. Prosiding Perken V. Jilid, 1, 63- 72.

Schultz, T. W. (1961a). Investment in Human Capital. New York. The Free Press, p 28-35.

World Bank. (2017). Nigeria. World Development Indicators. Retrieved from http://www.worldbank.org

World Health Organization. (2019). Civil society organizations to promote human rights in mental health and related areas: WHO QualityRights guidance module.

Simoes, M. (2006). Effects of education on economic growth: Evidence from Guatermala. MPRA Paper 23665, University Library of David Muradar \& Anatoli Vassilous, 2006. 